\title{
Influence of Receivables, Debt, Capital, and Assets to Profitability (Empirical research on Property \& Real Estate listed on Indonesia Stock Exchange year 2012-2016)
}

\author{
P Putranto ${ }^{1}$, M Triantoni Hendrias ${ }^{2}$ \\ $\left\{{ }^{1}\right.$ panji.putranto@mercubuana.ac.id, ${ }^{2}$ tonisuckseed@yahoo.co.id $\}$ \\ 1,2 Universitas Mercu Buana, Bekasi, Indonesia
}

\begin{abstract}
This research is to know or obtain the effects of receivable turnover, long-term debt, working capital and fixed assets of company to profitability. The purpose of this research is the Property Company listed on the Indonesia Stock Exchange which located in Jakarta. This research was conducted on Company audited Financial Statements of the period 2012 to 2016 by using the method of causal research therefore, the data analysis used is statistical analysis in the form of several linear regression test. The results of this research show that part, variable receivable turnover have a significant impact on profitability, while longterm debt, working capital and fixed assets have no significant impact on the profitability of the Property Company listed on the Indonesia Stock Exchange in 2012 until 2016.
\end{abstract}

Keywords: Debt, Receivable, Capital, Assets, Profitability, Property

\section{INTRODUCTION}

Property companies in Indonesia in the past five years have been up and down in achieving profit or profitability, it is influenced by social symptoms and internal symptoms of the company. In review of the social symptoms caused by lack of interest and the purchasing power of the public to the property while the review of the internal symptoms of the company caused the policies applied by the management of the company and the interests of of shareholders. Competitive competition between property companies also affects the ups and downs of profit or loss achievement (profitability). With the demands of corporate management and shareholders who want a maximum profit or profit eventually companies continue to invest developing property products to increase property sales despite the market conditions are sluggish And the profit gained last year is not maximized.

The company will generally conduct various activities to achieve its primary goal of profit or profitability that have been targeted in the company budget plan. With maximum profit or profitability, the company can maintain its business continuity (Going Concern) for a long period of time.

Business Continuity (Going Concern) A company can be seen from how to manage accounts receivable, fixed assets, long term debt and working capital. Effective management is carried out with the implementation of accounting records and reporting in accordance with the general applicable accruing rules. 
The purpose of this research was to acquire empirical evidence of the influence of turnover of receivables, long-term debt, working capital and the fixed assets to partial profitability. This research is expected to contribute well to the management of the company as a consideration to manage the company in order to increase profitability.

\section{RESEARCH METHOD}

The design of the research that will be used to resolve the problem is a causal research approach whereby the author wants to know about the influence of variables independent of the dependent variables.

In this research included in the free variables are receivables turnover, Natural logarithm of long term debt, working capital turnover and fixed-asset turnover. While the bound variable is Return On Asset (ROA).

The population in ths research is the entire property company listed on the Indonesia Stock Exchange as much as 39 (thirty nine) property companies.

The sampling technique used in this research is the Purposive Sampling method. sampling criteria are as follows:

A. The property company is listed on the Indonesia stock Exchange by reporting the results of audited consolidated financial statements in 2012-2016.

B. Property companies that have the necessary data completeness.

C. Property companies that booked profits or profits.

So that in this research will use data of 105 data, the amount gained from the calculation of property company population as much as 39 minus property companies that do not meet the criteria as much as 18 so that the samples in research As many as 21 companies

In this research, it is used is an archive data collection technique in the form of audited financial statements of companies using secondary data from the Indonesian Stock exchange.

The methods of analysis that will be used in this research are quantitative data analysis methods consisting of descriptive statistics, classic assumption test (normality, multicolonized and heteroskedastisity), linear regression analysis test Hypothesis Test (t-Statistic test).

The equation of regression between the influence of receivables turnover, long term debt, working capital and fixed assets to profitability using the following formula:

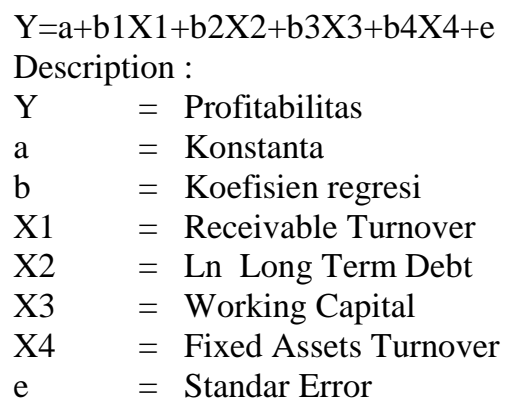

\section{RESULTS AND DISCUSSION}

Descriptive statistics are used to see the general overview of the data that heen collected in this research. Descriptive includes the mean value, Minimum value, maximum value and 
standard deviation value, which can be seen from the output of the following descriptive statistics table.:

\section{Desc riptive Statistics}

\begin{tabular}{ll|r|rr|r} 
& N & Mhimum & Maximum & Mean & $\begin{array}{c}\text { Std. } \\
\text { Deviation }\end{array}$ \\
\hline ROA & 105 & 0,001 & 0,240 & 0,071 & 0,051 \\
PMIK & 105 & 0,114 & 27,852 & 1,568 & 3,041 \\
PP & 105 & 0,642 & 216,628 & 16,630 & 29,488 \\
\hline PAT & 105 & 0,393 & 386,614 & 19,178 & 44,047 \\
\hline LrHP & 105 & 7,363 & 16,681 & 13,027 & 2,086 \\
\hline
\end{tabular}

The heteroskedastisity test aims to detect residual variations in regression model testing on all data and model regression can be used in research studies. If the remaining variation in the test is resolved it is called homoskedastisity and if the different residue variations are called heteroskedastisity. The heteroskedastisity test used in this research was to look at the Scatterplot picture patterns.

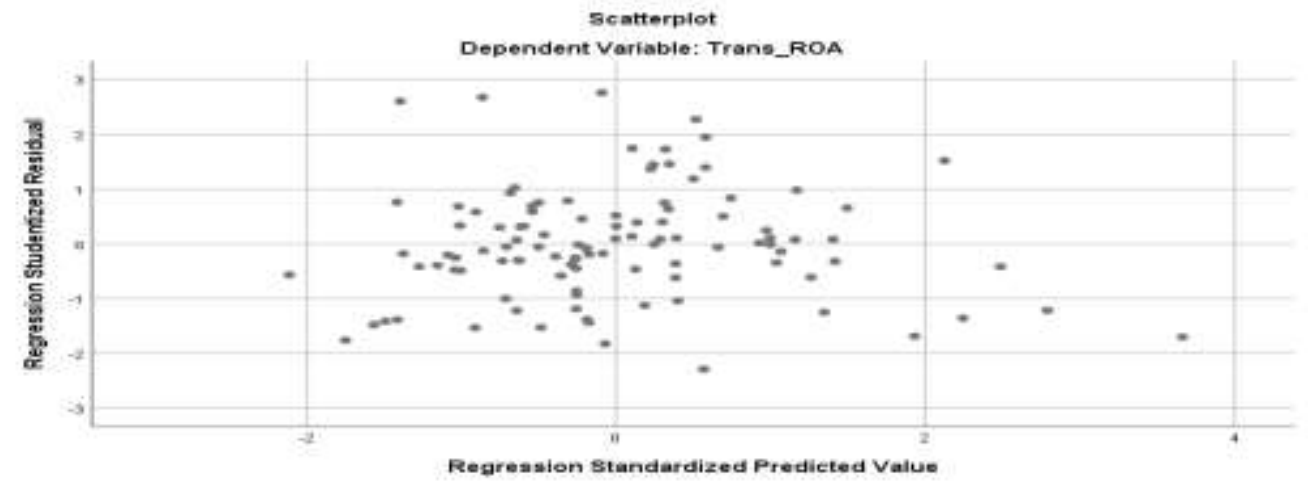

Based on the scatterplot image above, it can be seen that the data spreads evenly, not assembled in one place, and does not form a particular pattern so that it can be concluded that the regression test in this research did not occur a Heteroskedastisity problem.

Test normality in this research using one sample Kolmogorov Smirnov test with significance value $>0.05$ then data can be assumed to be distributed with normal and normal propability plot in the determination of normal or absence of data used in This research 


\section{One-Sample Kolmogorov-Smimov Test}

\begin{tabular}{llr} 
& & $\begin{array}{c}\text { Unstandandized } \\
\text { Residual }\end{array}$ \\
\hline N & & 105 \\
Nomal Parameters & Mean & 0.0000000 \\
Most Extreme & Std. Deviation & 0.08868464 \\
Differences & Absolute & 0.078 \\
& Positive & 0.078 \\
Test Statistic & Negative & -0.065 \\
Asymp. Sig. (2-tail ed) & & 0.078 \\
\hline a. Test distribution is Normal. & $.131^{\circ}$ \\
b. Calculated from data. &
\end{tabular}

The results of normality testing in the table above indicate that the value of Kolmogorov Smirnov Z is 0.078 and Asymp Sig (2 Tailed) amounted to 0, 131c of Asymp Sig value (2Tailed) in this research is great than 0.05 so that it can be concluded that the data In this research is distributed to normal and qualified test normality, so the data is feasible for use in research

Test normality using the histogram chart method by looking at the normal display of a symmetrical or bell-shaped histogram chart. It is shown in the picture 4.2 below shows a normal distrspark pattern whereby the data follows a normal curve so that it can be concluded that the data spread or distributed normal data. If the histogram chart shows normal distribution patterns then the regression model meets the normality test assumption.

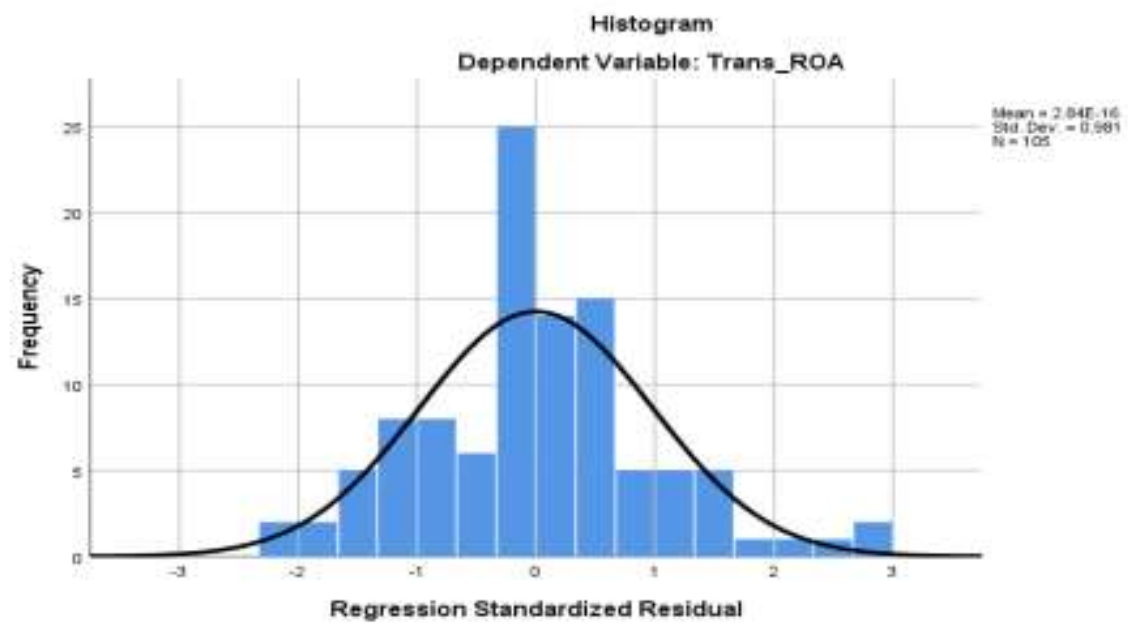

Test Nomalities using a graph of a P-plot spread can be seen from the spread of data on the diagonal source of the normal graph P-plot of regression standarized residual shown by the image below. Decision making is done if the point spreads around the line and follows the diagonal line means it shows normal distribution patterns and regression models that meet the normality test. 


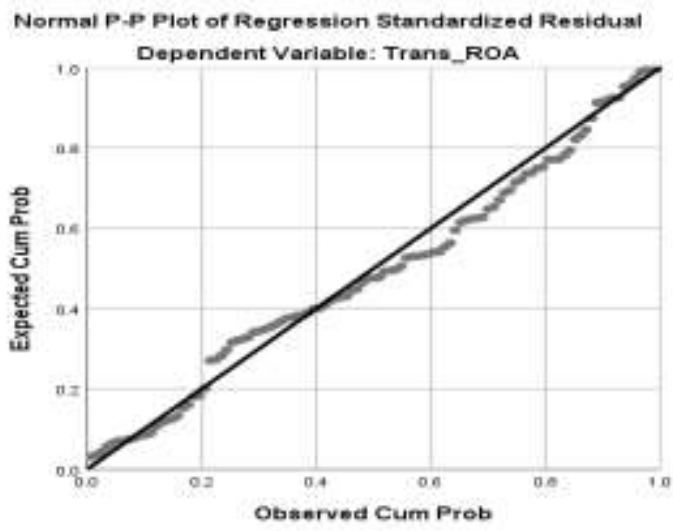

The test coefficient of determination is used to calculate the magnitude of influence between independent variables to dependent variables together. Research that uses one independent variable, the value of $\mathrm{R}$ Square which is used to see the test result of its coefficient of determination, while in this research using two or more independent variables, the Adjusted $\mathrm{R}$ Square is used to See coefficient of determination test result. This is done to measure and calculate the ability of regression model's in describing variations of dependent variables. The value of coefficient of determination is between zero and one $(0<\mathrm{R}<1)$. The table below shows the coefficient value of determining of the summary model.

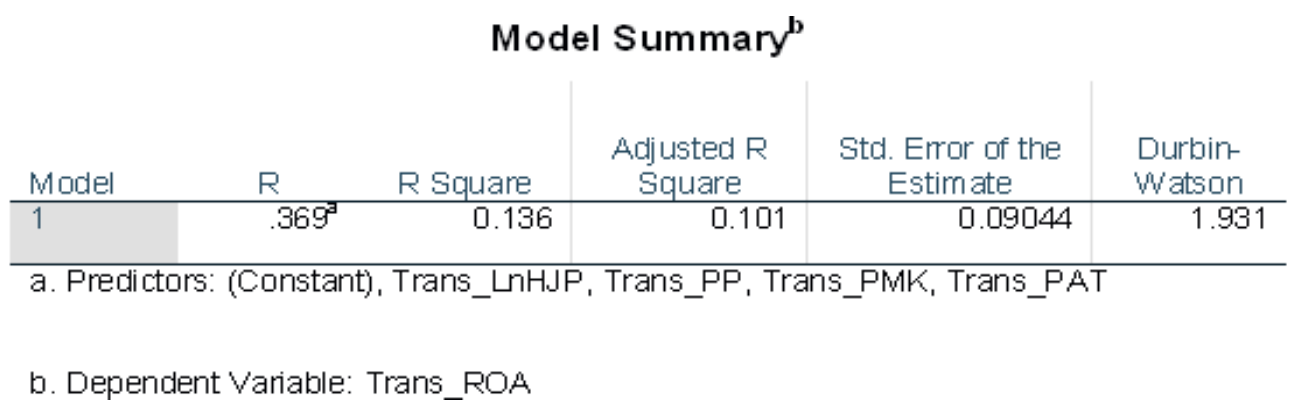

Based on the table coefficient of determination of $\mathrm{R}$ value (correlation coefficient) of 0.369 , this indicates the relationship of the turnover of receivables, working capital turnover, turnover of fixed assets and logarithm of long-term debt to very low or very weak profitability is only 36.9 percent and the Adjusted value of R Square (coefficient of determination) is 0.101 that means that 10.1 percent of dependent variables can be described by independent variables together while The remaining 90.9 percent is explained by other variables that are not researched. The default error of estimate value obtained by 0.0904 where the smaller the default error of estimate is then the regression model in this diffuser is approaching precisely in predicting or explaining the dependent variables. The value of Durbin Watson amounting to 1.931 in the range of values2 and +2 indicates that there is no autocorrelation between variables.

A multiple linear regression analysis is an analysis to measure the magnitude of influence between two or more independent variables against one dependent variable and predicts or describes the dependent variable by using an independent variable. This analysis is aimed at knowing whether or not there is an influence between variables, namely turnover 
receivable (X1) Working capital turnover (X2) Fixed assets (X3) and long term debt (X4), against profitability (Y). So that the regression model formula becomes as follows:

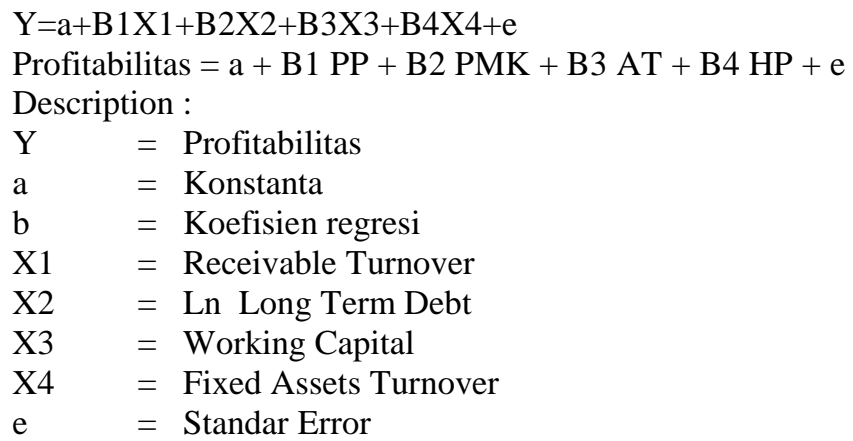

\begin{tabular}{|c|c|c|c|c|c|c|c|c|}
\hline & \multicolumn{8}{|c|}{ Coefficients ${ }^{a}$} \\
\hline & & \multicolumn{2}{|c|}{$\begin{array}{l}\text { Unstandardized } \\
\text { Coefficients }\end{array}$} & \multicolumn{3}{|l|}{$\begin{array}{l}\text { Standardized } \\
\text { Coefficients }\end{array}$} & \multicolumn{2}{|c|}{ Collinearity Statistics } \\
\hline \multicolumn{2}{|c|}{ Model } & $\mathrm{B}$ & Std. Error & Beta & $T$ & Sig. & Tolerance & VIF \\
\hline & (Constant) & 0.028 & 0.116 & & 0.238 & 0.812 & & \\
\hline & PMK & 0.023 & 0.014 & 0.154 & 1.605 & 0.112 & 0.933 & 1.072 \\
\hline & PP & 0.011 & 0.004 & 0.269 & 2.854 & 0.005 & 0.971 & 1.030 \\
\hline & PAT & 0.005 & 0.003 & 0.143 & 1.464 & 0.146 & 0.904 & 1.107 \\
\hline & LnH.JP & 0.040 & 0.032 & 0.124 & 1.251 & 0.214 & 0.882 & 1.133 \\
\hline
\end{tabular}

The equation of multiple linear regression is seen from the value present in column $\mathrm{B}$, the first line in column B shows constant (a) and the next line shows the coefficient of the variable independently, based on the table above can be inferred regression equation Multiple linear Studies in this research are as follows:

$\mathrm{Y}=\mathrm{a}+\mathrm{B} 1 \mathrm{X} 1+\mathrm{B} 2 \mathrm{X} 2+\mathrm{B} 3 \mathrm{X} 3+\mathrm{B} 4 \mathrm{X} 4+\mathrm{e}$ $\mathrm{ROA}=0,028+0,011 \mathrm{PP}+0,023 \mathrm{PMK}+0,005 \mathrm{AT}+0,040 \mathrm{HP}+\mathrm{e}$

From the test results of multiple linear regression test above, it can be noted in the equation of several linear regression research that:

1. A constant (a) of 0.028 indicates that if independent variables (receivables turnover, working capital turnover, fixed assets and long-term debts) are zero value then $\mathrm{Y}$ (profitability) is 0.028 units.

2. Variable regression coefficient of receivables turnover (B1) amounting to 0.011 this means that every increase in receivables is 1 percent, then the profitability (ROA) will rise by 1.1 percent so that it can be concluded that the regression coefficient of variables Turnover of receivables is positively valuable which means there is a positive connection between the turnover of receivables with profitability (ROA), therefore the better the turnover of receivables then the better the profitability (ROA).

3. Variable regression coefficient of working capital turnover (B2) of 0.023 This means that any increase in working capital turnover by 1 percent, then the profitability (ROA) 
will increase by 2.3 percent so that it can be concluded that the regression coefficient of working capital turnover positive variables which means a positive relationship occurred between the turnover of working capital with profitability (ROA), therefore the better the turnover of working capital then the better the profitability (ROA).

4. Variable regression coefficient of fixed assets Turnover (B3) of 0.005 This means that every fixed asset increase by 1 percent, then the profitability (ROA) will increase by 0.5 percent so that it can be concluded that variable regression coefficient Turnover of fixed assets is worth positive which means there is a positive relationship between the turnover of fixed assets with profitability (ROA), therefore the better the turnover of fixed assets then the better the profitability (ROA).

5. Variable regression coefficient of long-term debt of 0.040 this means that any longterm increase in debt by 1 percent, then the profitability (ROA) will rise by 4 percent can be concluded that the variable regression coefficient of term debt Long-worth positive means there is a positive relationship between long-term debt to profitability (ROA), therefore the better the use of long-term debt then the better the profitability (ROA).

Based on the explanation of analysis and the results of the research above obtained the following results:

\section{The influence of receivables turnover on profitability}

Based on research results there is a significant influence between the turnover of receivables on profitability. It is explained by the test result of T-calculate the receivables turnover of 2.854 (positive coefficient), while the T-table value of 1.984 is known T-count > T-table or $2.854>$ 1.984 with a significance value of 0.005 more From a $\alpha$ value of 0.05 . Thus, it was concluded that the turnover was significantly influential about this profitability in line with the research results of Julyana in 2016 and research of Dewi Lisnawati in 2017 that the turnover of receivables affects profitability. Then Ho or nil hypothesis is rejected and $\mathrm{H} 1$ or hypothesis one is accepted.

This means that the receivables are fast billed, it is likely because the risk of receivables is stuck and uncollectible is transferred to third parties such as banks and insurance. For example, the purchase of an apartment or house is usually done by the KPR so that the property company receives full payment from the bank for the purchase, and the buyer is new to the bank. Another possibility is that the management company manages to manage its standards well by minimizing the amount of uncollectible receivables and maximizing the turnover of receivables, thereby affecting the company's profitability to be good and Increased.

\section{Effect of long-term debt to profitability}

Based on the research results there is no significant influence between the long term debt to profitability. It is explained by the test results of the T-calculate variable long-term debt of 1.251 (positive coefficient), while the T-table value of 1.984 is then known T-count $<\mathrm{t}$-table or $1.251<1.984$ with a significance value of 0.214 more of a $\alpha$ value of 0.05 . It was concluded that long-term debt had no effect and had no effect and had no significant influence on this profitability in line with the results of Dewi Liana's 2015 research and Liza Nadira's research in 2013 for long term debt has no effect on profitability. Then the Ho or the nil hypothesis is accepted and $\mathrm{H} 2$ or hypothesis two is rejected.

This means that long-term use of corporate debt is more likely to be used for more costly operational activities that will be used for investment and business activities, which makes longterm debts not Significant impact on the company's profitability. 


\section{The effect of working capital turnover on profitability}

Based on the research results there is no significant influence between the turnover of working capital to profitability. This is explained by the test result of T-calculate the working capital turnover variable of 1.605, (positive coefficient), while the T-table value of 1.984 is then known T-count $<$ t-table or $1.605<1.984$ with its significance value of 0.112 Greater than the $\alpha$ value of 0.05 . It was concluded that the turnover of working capital had no effect and did not have a significant influence on this profitability in line with the research results of Hoiriya in 2015 and research Rinny Meidyastiani year 2014 that the turnover of capital Work has no effect on profitability. Then the Ho or the nil hypothesis was accepted and $\mathrm{H} 3$ or the three hypotheses rejected.

This means that the use of company working capital has not been used maximally and optimally in helping to improve the company's performance in this case of sales and business activities, so that working capital does not affect the profitability of the company.

\section{Effect turnover of fixed assets on profitability}

Based on the research results there is no significant influence between turnover of fixed assets on profitability. It is explained by the test result of T-calculate variable turnover of fixed assets of 1.464 (positive coefficient), while T-table value of 1.984 is known to T-calculate < ttable or $1.464<1.984$ with its significance value of 0.154 Greater than the $\alpha$ value of 0.05 . So it was concluded that the turnover of assets remained uninfluential and did not have a significant influence on this profitability in line with the research results of Heri Setiawan in 2010 and the research of Taufik in 2011 that the turnover of fixed assets has no effect on profitability. Then the Ho or the nil hypothesis was received and $\mathrm{H} 4$ or four hypothesis was rejected.

This means that the company's fixed assets are likely not to be used maximally for business activities so that the company's profitability is not much affected.

\section{CONCLUSIONS}

This research aims to empirically test the influence between receivables turnover, working capital turnover, fixed asset turnover and long-term debt to profitability in property companies listed on the Indonesia Stock Exchange year 2012 to 2016. Based on the results of the research and the discussion has been obtained the following conclusions:

1. The influence of the receivable turnover significantly affects profitability. This shows that the larger the receivables turnover, the greater the profitability. It is shown from the results of the discussion, where the regression coefficient of 0.011 is positive, T-count $>$ T-table or $2.854>1.984$ and the significance value of 0.005 is less than $\alpha$ by 0.05 . The management of the company performs good policies in managing its subsidiaries so that no receivables are not collectible or stalled and usually the risk of uncollectible receivables in the property sector is transferred to third parties such as banks and Insurance.

2. The influence of long-term debt does not significantly affect profitability. This indicates that long-term debt has no significant impact or no effect on the profitability shown by the results of the discussion, where the regression coefficient of 0.040 is positive, T-count of $<\mathrm{t}$-table or $1.251<1.984$ and Value The significance of 0.214 is greater than $\alpha$ by 0.05 . Management firms do not use the maximum use of long-term debt for investment activities and efforts to increase profitability, visible from the results of long-term debt research that may be used for operating activities so that no impact on profitability. 
3. The influence of working capital turnover does not affect significantly on profitability. This indicates that the turnover of working capital does not significantly impact or does not affect the profitability is shown from the results of the discussion, where the regression coefficient of 0.023 is positive value, T-count $<\mathrm{t}$-table or $1.605<1.984$ and Significance value of 0.112 is greater than $\alpha$ of 0.05 . The management of the company has not maximised the use of working capital as one way to increase profitability, seen from the research results that working capital has not influenced profitability.

4. The influence of turnover of fixed assets has no significant effect on profitability. This indicates that the turnover of fixed assets is less impactful or has no effect on the profitability is shown from the results of the discussion, where the regression coefficient of 0.005 is positive, T-count $<\mathrm{t}$-table or $1.464<1.984$ and Significance value of 0.154 is greater than $\alpha$ of 0.05 . The management of the company is likely to use most of its fixed assets only for operational activities but not used for other business activities that can improve and affect profitability.

Based on the results of research and discussion that has been done, the advice and suggesion provided is as follows:

1. Advice and suggesion for property companies

Property companies listed on the Indonesia Stock Exchange can effectively utilize the use of fixed assets, working capital and long-term debts to increase profitability even if those variables are not Too impactful and directly affect the profitability of the company. And for the turnover of corporate receivables, the management of the company can conduct policies such as aging age against receivables and management of receivables to make the receivables more quickly turn into cash or banks thereby increasing Profitability.

\section{Advice and suggesion for further researchers}

Further researchers are expected to add other independent variables that can affect the profitability of this due to the results of the low coefficient of determination (R) and Adjusted $\mathrm{R}$ Square below 50 percent. To improve the value of coefficient of determination $(\mathrm{R})$ and Adjusted R Square using different sector companies, extend the research period and replace or add independent variables. It is advised or recommended that the research approach accurate and precise results.

\section{REFERENCES}

[1] F. Azhari, "Ikhtilaf Ulama tentang Kedudukan Basmalah dalam Alfatihah Dibaca Ketika Shalat," Syariah: Jurnal Ilmu Hukum, vol. 15, no. 2, pp. 167-176, Desember 2015.

[2] A. I. Arifin, "Tindak Pidana Korupsi Menurut Hukum Pidana Islam," Lex et Societatis, vol. III, no. 1, pp. 72-82, Januari-Maret 2015.

[3] J. Rabain, "Perspektif Islam tentang Korupsi," An-Nida': Jurnal Pemikiran Islam, vol. 39, no. 2, pp. 187-198, Juli-Desember 2014.

[4] M. H. Umam, "Pandangan Islam tentang Korupsi," Teosofi: Jurnal Tasawuf dan Pemikiran Islam, vol. 3, no. 2, pp. 162-182, Desember 2013.

[5] A. Fawaid, "Islam, Budaya Korupsi, dan Good Governance," Karsa, vol. XVII, no. 1, pp. 18-26, April 2010. 
[6] T. Inayati and A. Nuryatin, "Simbol dan Makna pada Puisi Menolak Korupsi Karya Penyair Indonesia," Seloka: Jurnal Pendidikan Bahasa dan Sastra Indonesia, vol. 5, no. 2, pp. 163-171, November 2016.

[7] C. Ulya, N. E. Wardani and Y. Mujiyanto, "Muatan Pendidikan Antikorupsi dalam Mata Kuliah Pengkajian dan Apresiasi Puisi di Jawa Tengah dan Yogyakarta," Journal Indonesian Language Education and Literature, vol. 2, no. 1, pp. 60-75, Desember 2016.

[8] C. Ulya, N. E. Wardani and Y. Mujiyanto, "Metafora dalam Puisi Antikorupsi Karya Penyair Indonesia," Atavisme, vol. 19, no. 2, pp. 206-219, Desember 2016.

[9] S. Yunanto and F. A. Hamid, "Fragmentation and Conflict Among Islamic Political Parties in Indonesia During Reformasi Era: Anatomy, Factors, and Implications," Journal of Indonesian Islam, vol. 7, no. 2, pp. 250-260, Desember 2013.

[10] A. R. Mustapha, "Looking at Religion in Relation to The Moral Situation in Contemporary Nigeria," Journal of Islamic Studies and Culture, vol. 3, no. 1, pp. 7-10, June 2015.

[11] R. Mulgan, "Democracy and Political Corruption: Idealism Versus Realism," Policy Briefs Corruption and Anti-Corruption, pp. 1-7, 2006.

[12] M. B. Miles and A. M. Huberman, Analisis Data Kualitatif, Jakarta: UI Press, 1992. 